\title{
Increased seawater viscosity, Phaeocystis globosa spring bloom and Temora longicornis feeding and swimming behaviours
}

\author{
Laurent Seuront ${ }^{1,2, *}$, Dorothée Vincent ${ }^{3}$ \\ ${ }^{1}$ School of Biological Sciences, Flinders University, GPO Box 2100, Adelaide, South Australia 5001, Australia \\ ${ }^{2}$ South Australian Research and Development Institute, Aquatic Sciences, West Beach, South Australia 5022, Australia \\ ${ }^{3}$ Laboratoire d'Océanologie et de Géosciences, Centre National de la Recherche Scientifique (CNRS) UMR 8187, Maison de \\ la Recherche en Environnement Naturel, Université du Littoral-Côte d'Opale, 32 avenue Foch, 62930 Wimereux, France
}

\begin{abstract}
The suggested influence of increased seawater viscosity on the feeding and swimming behaviours of adult females of the calanoid copepod Temora longicornis was investigated during a Phaeocystis globosa spring bloom in the coastal waters of the eastern English Channel. Adult female gut contents did not exhibit any significant correlation with chlorophyll concentration or seawater excess viscosity over the course of the bloom. Instead, the highest gut contents were observed when the seawater viscosity was maximum (up to 4.6 centipoise [cP]), after a 5-fold decrease in chlorophyll concentration related to the formation of foam. This demonstrates that even high viscosity did not mechanically hamper zooplankton grazing. Gut contents were controlled by the taxonomic availability rather than the quantitative availability of phytoplankton-based food. This is consistent with the observed sustained egg production rates despite drastic changes in the composition of protist resource over the course of the bloom. Before and after the bloom (in the absence of P. globosa), T. longicornis exhibited similar swimming paths characterized by their large spatial extent and low curviness. In contrast, during the bloom their movements were spatially more localised, significantly slower and more convoluted. This behaviour is suggested as an adaptive strategy to optimise foraging activity during $P$. globosa blooms, which have been recently shown to generate high level of phytoplankton patchiness.
\end{abstract}

KEY WORDS: Zooplankton - Motility $\cdot$ Behaviour $\cdot$ Viscosity $\cdot$ Phaeocystis $\cdot$ Temora longicornis · Fractal

\section{INTRODUCTION}

The cosmopolitan phytoplankton genus Phaeocystis (Prymnesiophyceae) constitutes a key organism in driving global geochemical cycles, climate regulation and fisheries yield; for example see Schoemann et al. (2005) for a review. Of particular importance is the existence of a complex polymorphic life cycle exhibiting phase alternation between solitary flagellated cells and gelatinous colonies (Rousseau et al. 1994). Even if blooms of solitary cells occur, most large blooms are dominated by colonies (Peperzak et al. 2000), leading to the widely acknowledged belief that the success of Phaeocystis is largely a consequence of its ability to form gel-like colonies (Schoemann et al. 2005).

Colony formation seems to be an evolutionary advantage as colonies are apparently resistant to viral infection (Bratbak et al. 1998). Recent empirical evidence (Tang 2003) confirmed the long-held belief that Phaeocystis sp. colony formation is a defence strategy, 
as millimetre-scale (Peperzak et al. 2000) to centimetre-scale (Chen et al. 2002) colonies create a sizemismatch problem for small grazers (Weisse et al. 1994). Another consequence of the formation of gellike Phaeocystis colonies is the potential effects of phytoplankton-derived polymeric materials on seawater properties. More specifically, a positive correlation has been found between seawater viscosity and chlorophyll a (chl a) concentration during Phaeocystis blooms in the German Bight and the North Sea (Jenkinson \& Biddanda 1995). These early results have been amplified by studies conducted over the course of a P. globosa bloom in the eastern English Channel that showed the existence of positive and negative correlations between chlorophyll concentration and seawater viscosity before and after foam formation respectively (Seuront et al. 2006, 2007). This suggests that seawater rheological properties are mainly driven by extracellular materials associated with colony formation and maintenance rather than by cell composition and standing stock (Seuront et al. 2006). The resistance of Phaeocystis colonies to mesozooplankton grazing has also been attributed to a mechanical hindrance due to increased viscosity (Weisse et al. 1994). However, the increase in seawater viscosity during Phaeocystis sp. (Jenkinson \& Biddanda 1995) and P. globosa (Seuront et al. 2006, 2007) blooms has barely been investigated and its subsequent potential effects on zooplankton trophodynamics have never been demonstrated or investigated (Schoemann et al. 2005).

In the coastal zone of the eastern English Channel, blooms of the colony-forming Phaeocystis globosa are a recurring phenomenon and often coincide with maximal abundance of the calanoid copepod Temora longicornis (Fransz et al. 1992). P. globosa dominates the phytoplankton community, contributing over $73 \%$ of the total phytoplankton abundance and reaching maximum abundance of ca. $6 \times 10^{6}$ cells l$^{-1}$ (Seuront et al. 2006). While T. longicornis is able to remove up to $49 \%$ of the daily primary production (Dam \& Peterson 1993), grazing studies on $P$. globosa single cells are still controversial (see Nejstgaard et al. 2007 for a review). Relatively high (Koski et al. 2005) and low (Cotonnec et al. 2001) feeding rates have been reported for $T$. longicornis grazing on P. globosa. P. globosa often represents a poor food source for zooplankton production and growth (Klein Breteler \& Koski 2003). This suggests that copepods switch to alternative food sources during the bloom (e.g. ciliates and dinoflagellates; Gasparini et al. 2000, Koski et al. 2005). Since swimming and feeding behaviours are intrinsically linked in most calanoid copepods, we studied the swimming and feeding responses of $T$. longicornis before, during and after a $P$. globosa bloom, to reveal whether grazing by $T$. longicornis adult females is affected by biologically- induced modification of seawater viscosity and potentially related to the protist cell composition and standing stock.

\section{MATERIALS AND METHODS}

Field site and sampling strategy. The sampling site was located at the inshore station $\left(50^{\circ} 40^{\prime} 75^{\prime \prime} \mathrm{N}\right.$, $1^{\circ} 31^{\prime} 17^{\prime \prime}$ E) of the Service d'Observation du Milieu Littoral (SOMLIT) network in the coastal waters of the eastern English Channel. The eastern English Channel is characterized by its megatidal range of between 3 and $9 \mathrm{~m}$. Tides are characterized by a residual circulation parallel to the coast, with nearshore coastal waters drifting from the English Channel into the North Sea. Coastal waters are influenced by freshwater run-off from the Seine estuary to the Strait of Dover. This 'Coastal Flow' is separated from offshore waters by a tidally maintained frontal area. The inshore water mass is characterized by its low salinity, turbidity, phytoplankton richness and productivity, when compared with the oceanic offshore waters. The sampling site was chosen as the physical and hydrological properties encountered here are representative of the inshore water masses of the eastern English Channel. Sampling was conducted weekly at high tide before, during and after the Phaeocystis globosa bloom in the eastern English Channel from February to June 2004.

Water temperature $\left({ }^{\circ} \mathrm{C}\right.$ ) and salinity (PSU) profiles from surface to bottom were measured using a Seabird SBE 19 or Seabird SBE 25 Sealogger CTD at each sampling date. The maximum depth never exceeded $25 \mathrm{~m}$. Water samples were taken from sub-surface waters using 51 Niskin bottles. Chl a concentrations and seawater viscosity were systematically estimated from the same water samples. The composition and standing stock of auto-, hetero- and mixotrophic protists were investigated from 11 sub-surface samples.

At each sampling date, surface seawater (40 l) was collected and stored in a polycarbonate carboy for further use in the laboratory during the behavioural experiments. Zooplankton were collected with a WP2 net (200 $\mu \mathrm{m}$ mesh size) fitted with a $1 \mathrm{l}$ filtering codend hauled horizontally $\left(<1 \mathrm{~m} \mathrm{~s}^{-1}\right.$, mean duration less than $10 \mathrm{~min}$ ) through the upper $5 \mathrm{~m}$ of the water column. Aliquots of this sample were immediately deepfrozen in liquid nitrogen to minimize faecal pellet production (Saiz et al. 1992) and kept frozen at $-80^{\circ} \mathrm{C}$ in the dark until gut content analysis. Specimens were also gently diluted in $30 \mathrm{l}$ isotherm tanks using in situ seawater and transported within $1 \mathrm{~h}$ to the laboratory. Temora longicornis adult females were then immediately sorted by pipette under a dissecting microscope and acclimated for $2 \mathrm{~h}$ in a $2 \mathrm{l}$ beaker 
containing fresh in situ seawater prior to the behavioural experiments.

All the parameters considered here were investigated from sub-surface samples (1) because previous experiments conducted from the same inshore sampling site always showed the water column to be vertically homogenized (e.g. Seuront et al. 2006), and (2) to avoid any confusing interpretation that could result from benthic and tychoplanktonic phytoplankton resuspended in the bottom layer of the water column, as their proportion is highly variable at different time scales and strongly depends on the energy dissipation rates of the environment (e.g. spring/neap tide cycle, season, wind stress).

Chlorophyll analysis. Chlorophyll concentrations were estimated from $500 \mathrm{ml}$ seawater samples. Samples were vacuum filtered on Whatman GF/F glass fibre filters (porosity $0.45 \mu \mathrm{m}$ ). Chlorophyllous pigments were extracted by direct immersion of the filters in $5 \mathrm{ml}$ of $100 \% \mathrm{~N}, \mathrm{~N}$-dimethylformamide, and actual extractions were made in the dark at $-20^{\circ} \mathrm{C}$ for $12 \mathrm{~h}$. Concentrations of chl a in the extracts were determined following Strickland \& Parsons (1972) using a Turner 450 fluorometer previously calibrated with chl a extracted from Anacystis nidulans (Sigma Chemicals, St Louis).

Protist community composition. For micro- and nanoplankton analyses $1 \mathrm{l}$ samples were preserved in the field with acid Lugol's iodine solution (2\% final concentration) and stored in the dark at $4^{\circ} \mathrm{C}$. Enumeration was carried out using the Utermöhl (1958) settling method within a month after collection (typically
7 to 21 d), a time period that does not lead to any significant changes in Phaeocystis globosa colony size and abundance after Lugol's preservation $(\mathrm{p}>0.05, \mathrm{n}=$ 357; L. Seuront unpubl. data). Sub-samples of 10 to $20 \mathrm{ml}$ in sizewere allowed to settle for $24 \mathrm{~h}$ in Hydrobios counting chambers and settled slides were observed by inverted microscopy (Olympus, 200× and $400 \times$ magnification). Autotrophic protists were identified according to Sournia (1986), Ricard (1987), Paulmier (1997) and Tomas (1997). Cells were measured with an eyepiece micrometer and corresponding biovolumes $\left(\mu^{3}\right)$ were calculated by relating the shape of organisms to a standard geometric form of known volume. Cell biovolumes were converted to carbon biomass following Menden-Deuer \& Lessard (2000) and Menden-Deuer et al. (2001).

The first appearance of Phaeocystis globosa colonies, their size (total length and width) and shape were determined throughout the survey according to Rousseau et al. (1990). Small colonies $(\leq 200 \mu \mathrm{m}$ maximum dimension) were often spherical, medium colonies (200 to $350 \mu \mathrm{m})$ were either spherical or ellipsoid, and large colonies $(>350 \mu \mathrm{m})$ were either ellipsoid or typically ghost colonies (i.e. large flat areas of skin-like matrix). The proportion of ghost colonies markedly increased over the course of the bloom (Table 1). The number of cells per colony was determined by inverted microscopy under contrast phase illumination, i.e. cells appeared brighter than their background. For large ghost, small spherical and ellipsoid colonies, direct enumeration was carried out by counting the number of cells within each colony with a $20 \times$ Plan Ph1 0.50 NA objective. For large

Table 1. Time course of measured seawater viscosity $\eta_{m}(\mathrm{cP})$, physically controlled component of seawater viscosity $\eta_{\mathrm{T}, \mathrm{S}}(\mathrm{cP})$ estimated in the laboratory from viscosity measurements conducted on filtered $(0.20 \mu \mathrm{m}$ mesh size), and seawater excess viscosity $\eta$ $(\%)$; length $(\mu \mathrm{m})$, width $(\mu \mathrm{m})$, shape $(\mathrm{S}=$ spherical, $\mathrm{E}=$ ellipsoid, $\mathrm{G}=$ ghost colony [large flat areas of skin-like matrix]) of Phaeocystis globosa colonies in order of importance; range of $P$. globosa cells per colony; and mean prosome length (PL) of Temora longicornis adult females (mm). The numbers in parentheses are SD values

\begin{tabular}{|c|c|c|c|c|c|c|c|c|c|c|}
\hline \multirow[t]{2}{*}{ Bloom period } & \multirow[t]{2}{*}{ Date } & \multicolumn{3}{|c|}{ Seawater viscosity } & \multicolumn{4}{|c|}{ P. globosa colonies } & \multirow{2}{*}{\multicolumn{2}{|c|}{$\begin{array}{l}\text { T. longicornis } \\
\text { PL (mm) }\end{array}$}} \\
\hline & & $\eta_{\mathrm{m}}(\mathrm{cP})$ & $\eta_{\mathrm{T}, \mathrm{S}}(\mathrm{cP})$ & $\eta(\%)$ & Length $(\mu \mathrm{m})$ & Width $(\mu \mathrm{m})$ & Shape & cells colony $^{-1}$ & & \\
\hline \multirow{3}{*}{$\begin{array}{l}\text { Pre-bloom } \\
\left(\mathrm{B}_{0}\right)\end{array}$} & 16 Feb 2004 & - & - & - & - & - & - & - & - & - \\
\hline & 2 Mar 2004 & 1.63 & 1.49 & 9.2 & - & - & - & - & 0.96 & $(0.04)$ \\
\hline & 10 Mar 2004 & 1.71 & 1.56 & 9.8 & - & - & - & - & 0.98 & $(0.06)$ \\
\hline \multirow{6}{*}{$\begin{array}{l}\text { Bloom/no foam } \\
\left(\mathrm{B}_{1}\right)\end{array}$} & 22 Mar 2004 & 2.04 & 1.57 & 29.6 & - & - & - & - & 0.98 & $(0.02)$ \\
\hline & 29 Mar 2004 & 2.93 & 1.49 & 96.8 & $70-627$ & $30-275$ & $\mathrm{~S}, \mathrm{E}$ & $8-259$ & 0.99 & $(0.09)$ \\
\hline & 8 Apr 2004 & 3.68 & 1.41 & 161.2 & $120-570$ & $60-315$ & $\mathrm{~S}, \mathrm{E}$ & $15-144$ & 0.96 & $(0.09)$ \\
\hline & 13 Apr 2004 & 2.92 & 1.40 & 108.9 & $60-374$ & $60-180$ & $\mathrm{~S}, \mathrm{E}, \mathrm{G}$ & $16-127$ & 0.99 & $(0.03)$ \\
\hline & 20 Apr 2004 & 3.45 & 1.41 & 144.6 & $60-784$ & $40-394$ & $\mathrm{G}, \mathrm{S}, \mathrm{E}$ & $9-194$ & 0.98 & $(0.01)$ \\
\hline & 30 Apr 2004 & 3.80 & 1.38 & 175.7 & $90-1060$ & $90-955$ & $\mathrm{G}, \mathrm{S}, \mathrm{E}$ & $15-566$ & 1.00 & $(0.02)$ \\
\hline \multirow{4}{*}{$\begin{array}{l}\text { Bloom/foam } \\
\left(\mathrm{B}_{2}\right)\end{array}$} & 7 May 2004 & 3.13 & 1.37 & 128.2 & - & - & - & - & 1.03 & $(0.03)$ \\
\hline & 18 May 2004 & 4.58 & 1.32 & 247.1 & $200-1146$ & $80-1146$ & G & $40-1201$ & 0.98 & $(0.07)$ \\
\hline & 25 May 2004 & 4.17 & 1.29 & 223.0 & $265-1040$ & $40-765$ & G & $25-55$ & 1.04 & $(0.06)$ \\
\hline & 3 Jun 2004 & 2.09 & 1.25 & 67.4 & - & - & - & - & 0.95 & $(0.04)$ \\
\hline \multirow{2}{*}{$\begin{array}{l}\text { Post-bloom } \\
\left(\mathrm{B}_{3}\right)\end{array}$} & 15 Jun 2004 & 1.36 & 1.20 & 13.2 & - & - & - & - & 1.03 & $(0.02)$ \\
\hline & 8 Jul 2004 & 1.23 & 1.15 & 7.3 & - & - & - & - & 0.99 & $(0.02)$ \\
\hline
\end{tabular}


spherical and ellipsoid colonies, cell counting was carried out by sequentially focusing through each colony with a 10× Plan Ph1 $0.25 \mathrm{NA}$ objective. While the enumeration of cells in large colonies may be tedious and problematic (Verity et al. 2007), the linear regressions found between number of cells per colony and the colony volume did not significantly differ between colony types (analysis of covariance, $p>0.05$ ). This results in the number of cells per colony, $N$, being highly significantly correlated $(\mathrm{p}<0.001, \mathrm{n}=80)$ with colony volume, $V\left(\mathrm{~mm}^{3}\right)$, as $\log N=0.33 \log V+2.53$. In addition, a close examination of the residuals of this regression did not exhibit any significant local slope that might have been indicative of a bias related to an underestimation of cell number in large colonies. The contribution of Phaeocystis to carbon biomass was estimated using the conversion factor of $122 \mathrm{pgC} \mathrm{cell}^{-1}$ defined by van Rijssel et al. (1997), which included colonial mucus. Due to their heterotrophic status, some of the dinoflagellates counted during the survey (Gyrodinium sp.) were analysed separately. Since Lugol's preservation does not allow unambiguous identification of ciliates, ciliate enumeration considered total ciliates and mainly included oligotrichous ciliates (30 to $40 \mu \mathrm{m}$ length) and large tintinnids (>60 $\mu \mathrm{m}_{\text {; }}$ Acineta sp.). Ciliate carbon biomass was calculated from cell biovolumes (estimated as described previously) using a volume-to-carbon conversion factor of $0.19 \mathrm{pgC} \mathrm{m}^{-3}$ that accounts for cell shrinkage (Putt \& Stoecker 1989). No taxonomic data were available on May 7.

Seawater excess viscosity measurements. Viscosity measurements were conducted with a portable ViscoLab400 viscometer (Cambridge Applied Systems) following Seuront et al. $(2006,2007)$ from $10 \mathrm{ml}$ water samples stored in the dark in a bucket maintained at in situ temperature. Viscosity was estimated in triplicate from 2 to $3 \mathrm{ml}$ water samples poured into a small chamber, where a low mass stainless steel piston is magnetically forced back and forth with a $230 \mu \mathrm{m}$ piston-cylinder gap size. Because the force driving the piston is constant, the time required for the piston to move back and forth into the measurement chamber is proportional to the viscosity of the fluid. The more viscous the fluid the longer it will take the piston to move through the chamber, and vice versa. As viscosity is influenced by temperature and salinity, the measured viscosity $\eta_{\mathrm{m}}$ in centipoise (cP) is the sum of a physically controlled viscosity component $\eta_{\mathrm{T}, \mathrm{S}}(\mathrm{cP})$ and a biologically controlled viscosity component $\eta_{\text {Bio }}(\mathrm{cP})$, i.e.:

$$
\eta_{\mathrm{m}}=\eta_{\mathrm{T}, \mathrm{S}}+\eta_{\text {Bio }}
$$

To ensure that the viscosity component $\eta_{\text {Bio }}$ corresponds to extra-colonial polymeric materials contained in the bulk phase seawater, and not to intra-colonial materials released during the measurement through the disruption of colonies in the chamber of the viscometer, viscosity measurements were conducted on sub-samples where colonies were removed using a Pasteur pipette under a dissecting microscope (100× magnification). The physically controlled component $\eta_{\mathrm{T}, \mathrm{S}}$ was estimated in the laboratory from viscosity measurements conducted on filtered $(0.20 \mu \mathrm{m}$ mesh size) seawater from the same samples. The biologically induced excess viscosity, $\eta_{\text {Bio, }}$ was subsequently estimated with confidence from each water sample as $\eta_{\text {Bio }}=\eta_{\mathrm{m}}-\eta_{\mathrm{T}, \mathrm{S}}$. The related relative excess viscosity $\eta$ is, thus, given by (Seuront et al. 2006, 2007):

$$
\eta=\left(\eta_{\mathrm{m}}-\eta_{\mathrm{T}, \mathrm{S}}\right) / \eta_{\mathrm{T}, \mathrm{S}}
$$

Before each viscosity measurement, temperature and salinity of the seawater sample were simultaneously measured using a Hydrolab probe. Between each viscosity measurement, the viscometer chamber was carefully rinsed with deionised water and bulk phase seawater filtered through $0.2 \mu \mathrm{m}$ pore size filters to avoid any potential dilution of the next sample. To avoid any bias related to temperature changes, all viscosity measurements were conducted in a temperature-controlled room set up at in situ temperature.

Zooplankton gut content. In the laboratory, 5 Temora longicornis adult females were picked from the frozen samples under a binocular microscope and cool light. Organisms were rinsed with filtered seawater, transferred and ground with a tissue homogenizer in $5 \mathrm{ml}$ of $100 \% \mathrm{~N}, \mathrm{~N}$-dimethylformamide, and chlorophyllous pigments were then extracted in the dark at $-20^{\circ} \mathrm{C}$ for $12 \mathrm{~h}$. Gut content was analysed fluorometrically (Mackas \& Bohrer 1976), and gut fluorescence readings were taken before and after acidification with $50 \mu \mathrm{l}$ of $10 \% \mathrm{HCl}$ using a Turner 450 fluorometer. Gut contents (GC hereafter) were converted to equivalent chlorophyll ingested following Dagg \& Wyman (1983).

Video setup and behavioural observations. For each date, 5 behavioural experiments were done with Temora longicornis adult females in a temperature controlled dark room $\left(20^{\circ} \mathrm{C}\right)$ in a $21(20 \times 20 \times 5 \mathrm{~cm})$ Plexiglas behavioural container described previously by Seuront (2006). Prior to each experiment, an individual was selected from the female stock, transferred to the experimental filming setup, which was filled with fresh in situ seawater, and allowed to acclimatise for $15 \mathrm{~min}$. The 2D trajectory of the copepod was

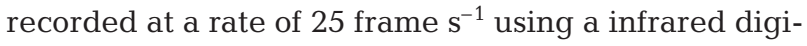
tal camera (DV Sony DCR-PC120E) facing the front view of the experimental container. Two arrays of 72 infrared light emitting diodes (LEDs), each mounted on a printed circuit board about $9.3 \mathrm{~cm}$ long and $4.9 \mathrm{~cm}$ wide connected to a $12 \mathrm{~V}$ DC power supply, provided the only light source. All experiments were conducted 
in the dark and at night to avoid any potential behavioural artefact related to the diel light cycle.

Each female was recorded swimming for $60 \mathrm{~min}$, after which valid video clips were identified for analysis. Valid video clips consisted of pathways in which the animals were swimming freely, at least 2 body lengths away from any chamber walls or the surface of the water. Between 6 and 30 swimming paths were considered for each sampling date and female. Duration of individual observations varied, and swimming path durations ranged from $15 \mathrm{~s}$ to $2 \mathrm{~min}$. Although we considered copepods filmed in one 2D aquarium only, we ensured that the behaviour was representative of the species for each experiment by qualitatively observing the general swimming behaviour of females Temora longicornis in other 3D aquaria.

Before each experiment, $500 \mathrm{ml}$ of the seawater used for the behavioural experiment were vacuum filtered on Whatman GF/F glass-fibre filters for chlorophyll concentration measurements. Before and after each experiment, triplicate $3 \mathrm{ml}$ seawater samples were measured for viscosity. No significant differences were found between chlorophyll concentrations estimated from in situ and experimental water (Wilcoxon-MannWhitney test, $\mathrm{p}>0.05)$. Also, no significant differences were found between the seawater excess viscosity estimated from in situ water samples and the experimental water from both before and after each behavioural experiment (Kruskal-Wallis test, p > 0.05). At the end of the experiment, individuals were sorted by pipette and preserved in formalin for size determination.

Image analysis and behavioural analysis. Selected video clips were captured (DVgate Plus, 25 frames s ${ }^{-1}$ ) as MPEG movies and converted into QuickTime ${ }^{\mathrm{TM}}$ movies (QuickTime Pro), after which the $x$ and $y$ coordinates of swim paths were automatically extracted and subsequently combined into a 2D picture using LabTrack software (DiMedia, Kvistgård, Denmark). The time step was always $0.04 \mathrm{~s}$, and output sequences of $(x, y)$ coordinates were subsequently used to characterise the motility.

Swimming paths may be characterised by a variety of measures, including for example path length (the total distance travelled, or gross displacement), move length (the distance travelled between consecutive points in time), move duration (the time interval between successive locations), turning angle (the difference in direction between 2 successive moves), turning rate (the turning angle divided by move duration) and net displacement (the linear distance between starting and ending point); see Seuront et al. (2004) for a review. As discussed elsewhere (Seuront et al. 2004), all of these metrics are implicitly a function of their measurement scale, and there is no single scale at which swimming paths can be unambiguously des- cribed. This is not the case for fractal dimensions, which are scale-independent. However, because fractal dimensions have seldom been used in zooplankton behavioural studies (see Seuront et al. 2004 for a review), more common behavioural measures were also used to provide a reference framework for the reader to make comparisons with previous studies having similar temporal resolution.

Swimming activity index: The level of activity of a copepod is estimated as the percentage of time allocated to swimming. The activity index $A_{i}$ is then defined as:

$$
A_{i}=100 \times \frac{t_{\text {track }}}{t_{\text {swim }}}
$$

where $t_{\text {track }}$ and $t_{\text {swim }}$ are the duration of a swimming path and the time a copepod spent swimming, respectively.

Swimming speed: The distance $d_{t}(\mathrm{~mm})$ between 2 points in a 2-dimensional space was computed from the $x$ and $y$ coordinates as:

$$
d_{t}=\left[\left(x_{t+1}-x_{t}\right)^{2}+\left(y_{t+1}-y_{t}\right)^{2}\right]^{1 / 2}
$$

where $\left(x_{t}, y_{t}\right)$ and $\left(x_{t+1}, y_{t+1}\right)$ are the positions of a copepod at time $t$ and $t+1$, respectively. The swimming speeds over consecutive tracking intervals (i.e. $40 \mathrm{~ms}$ ) were subsequently estimated as:

$$
v=d_{t} \times f
$$

where $f$ is the sampling rate of the camera, i.e. $f=25$ frames $\mathrm{s}^{-1}$. Average swimming speed and their SD values were measured over the duration of each individual track.

Net-gross displacement ratio (NGDR): The NGDR provides a measure of the relative linearity of copepod swimming paths as:

$$
\mathrm{NGDR}=\frac{\mathrm{ND}}{\mathrm{GD}}
$$

where ND and GD are the net and gross displacements of a copepod, which correspond to the shortest distance between the starting and ending point of the trajectory and the actual distance travelled by the copepod, respectively. Low NGDRs imply more curved, convoluted trajectories than higher NGDRs. The NGDRs were computed at the smallest available resolution $(0.04 \mathrm{~s})$ for each i ndividual track. The gross displacement may also be expressed as the sum of the individual distances $d_{t}$ travelled during a path of duration $t_{\text {track }}$ as:

$$
\mathrm{GD}=d=\sum_{t=1}^{t_{\text {track }}} d_{t}
$$

Fractal dimension D: The fractal dimension $D$, considered here as a scale-independent descriptor of swim- 
ming behaviour, is bounded between $D=1$ and $D=2$. When an organism moves along a completely linear path, the distance travelled (i.e. the GD) equals the displacement between the start and the finish (i.e. the ND), and $D=1$. In the opposite extreme instance of curviness, when the motions are so complex that the path fills the whole available space (i.e. for the case of Brownian motion in 2 dimensions, $D=2$ ). $D$ then provides a measure of path complexity bounded between the linear and Brownian movements. The reliability of fractal dimension estimates was ensured through the application of 2 different methods, the compass and box-counting methods, on all the available swimming paths.

Using the compass method, the fractal dimension was estimated by measuring the length $L$ of a path at various scale values $\delta$. The procedure is analogous to moving a set of dividers (like a drawing compass) of fixed length $\delta$ along the path. The estimated length of the path is the product of $N$ (number of compass dividers required to 'cover' the path) and the scale factor $\delta$. The number of dividers necessary to cover the object then increases with decreasing measurement scale, giving rise to the power-law relationship:

$$
L(\delta) \propto \delta^{m}
$$

where $\delta$ is the measurement scale and $L(\delta)$ is the measured length of the path. Practically, the compass fractal dimension $D_{C}$ is estimated from the slope $m$ of the plot of $\log L(\delta)$ versus $\log \delta$ for various values of $\delta$ where

$$
D_{c}=1-m
$$

Using the box-counting method, the fractal dimension $D_{b}$ is estimated by superimposing a regular grid of boxes of side length $\lambda$ on the object and counting the number of 'occupied' boxes. This procedure is repeated using different values for $\lambda$. The surface occupied by a path is then estimated with a series of counting boxes spanning a range of surfaces down to some small fraction of the entire surface. The number of occupied boxes increases with decreasing box size, leading to the following power-law relationship:

$$
N(\lambda) \propto \lambda^{-D_{b}}
$$

where $\lambda$ is the box size, $N(\lambda)$ is the number of boxes occupied by the path, and $D_{b}$ is the box-counting fractal dimension, also often referred to as the box dimension. This dimension $D_{b}$ is estimated from the slope of the linear trend of the plot of $\log N(\lambda)$ versus $\log \lambda$. Because slight reorientation of the overlying grid can produce different values of $N(\lambda)$, the fractal dimensions $D_{b}$ have been estimated for rotation of the initial $2 \mathrm{D}$ grid of $5^{\circ}$ increments from 0 to $45^{\circ}$ (Seuront et al. 2004).

An objective statistical criterion was defined to decide upon an appropriate range of scales to include in the regression and to ensure that the fractal dimension itself is not scale-dependent. A regression window of a varying width that ranges from a minimum of 5 data points (the least number of data points to ensure the statistical relevance of a regression analysis) to the entire data set was considered. The smallest window was slid along the entire data set at the smallest available increments, with the whole procedure iterated ( $\mathrm{n}-4)$ times, where $\mathrm{n}$ is the total number of available data points. Within each window and for each width, the coefficient of determination $\left(\mathrm{r}^{2}\right)$ and the sum of the squared residuals for the regression were estimated. The values of $\delta$ (Eq. 8) and $\lambda$ (Eq. 10), which maximized the coefficient of determination and minimized the total sum of the squared residuals (Seuront et al. 2004), were subsequently used to define the scaling range and to estimate the related dimensions $D_{c}$ and $D_{b}$.

Statistical analyses. The distributions of the compass fractal dimension, $D_{C}$, and the box-counting fractal dimension, $D_{b}$, were compared using the WilcoxonMann-Whitney U-test (Siegel \& Castellan 1988). Multiple comparisons between sampling dates were conducted using the Kruskal-Wallis test (KW test hereafter), and the Jonckheere test for ordered alternatives (J test hereafter, Siegel \& Castellan 1988) was used to identify distinct groups of measurements. Correlation between variables was investigated using Kendall's coefficient of rank correlation, $\tau$. Kendall's coefficient of correlation was used in preference to Spearman's coefficient of correlation, $\rho$, because Spearman's $\rho$ gives greater weight to pairs of ranks that are further apart, while Kendall's $\tau$ weights each disagreement in rank equally.

\section{RESULTS}

\section{Environmental conditions}

No vertical stratification was observed in temperature or salinity profiles. The lack of stratification indicates a well-mixed water column over the course of the survey. This is consistent with the high values previously found at the same location for vertical shear activity and turbulent kinetic energy dissipation rates, characterising strongly mixed tidal flows (Seuront 2005). Vertically averaged salinity were fairly stable, with fluctuations ranging between 33.80 and 34.54 PSU $(34.20 \pm 0.22 \mathrm{PSU}, \bar{x} \pm \mathrm{SD})$. In contrast, temperature fluctuated from $6.13^{\circ} \mathrm{C}$ on March 3 to $17.54^{\circ} \mathrm{C}$ on July 8 , and exhibited a clear seasonal cycle. These temperature and salinity values are congruent with previous measurements done at the seasonal scale in the inshore waters of the eastern English Channel. 


\section{Chlorophyll concentration and seawater excess viscosity}

The mean chl a concentrations estimated in subsurface waters ranged from 0.91 to $49.68 \mu \mathrm{g} \mathrm{l}^{-1}(15.01 \pm$ $\left.3.91 \mu \mathrm{g} \mathrm{l}^{-1}, \bar{x} \pm \mathrm{SD}\right)$. The phytoplankton bloom started in early March and reached its peak value on April 30, with values of chlorophyll up to $50 \mathrm{\mu g}^{-1}$ (Fig. 1a). The bloom was characterized by a significant increasing trend (Kendall's $\tau, \mathrm{p}<0.05$ ) in chlorophyll concentration until April 30, followed by a 5-fold decrease observed on May 7 (Fig. 1a) that coincided with the formation of foam in the turbulent surf zone (Fig. 1a). The time courses of chlorophyll concentration and Phaeocystis globosa colony size were similar before the formation of foam, resulting in significantly positive correlation ( $\mathrm{p}<0.05)$. After foam formation, despite an increasing proportion of senescent colonies (+25\%), colony size kept increasing while phytoplankton biomass exhibited a sharp decrease (Table 1). Microscopic examination of colony shape at that time revealed that most colonies were disrupted and, thus, formed large flat areas of skin-like matrix. Seawater viscosity $\eta_{\mathrm{T}, \mathrm{S}}$ ranged from 1.23 to $4.58 \mathrm{cP}$ (Table 1). Taking into account the physically controlled viscosity component $\eta_{\mathrm{T}, \mathrm{S}}$, which ranged from 1.15 to $1.57 \mathrm{cP}$ (Table 1), the excess viscosity $\eta$ ranged from 9.2 to $247.1 \%$ (107.6 \pm $20.8 \%, \bar{x} \pm \mathrm{SD}$ ). The time course of seawater viscosity is characterized by a significant increasing trend ( $\mathrm{p}<$ 0.05) until May 18 (Fig. 1b), followed by a sharp decrease at the end of the foam formation period.

\section{Protist taxonomy and abundance}

Six main protists groups of decreasing cell concentrations were identified: the Prymnesiophyceae Phaeocystis globosa, nanoflagellates, diatoms, cryptophytes, dinoflagellates and ciliates (Table 2). P. globosa cells were first observed at the end of March, and disappeared at the beginning of June. Their concentration ranged from $0.8 \times 10^{6}$ to $5.5 \times 10^{6}$ cells $^{-1}$, representing between 40.4 and $80.5 \%$ of the total protist abundance. The related carbon biomass ranged from 99.8 to $676.4 \mu \mathrm{gC}^{-1}$, i.e. between 7.4 and $78.5 \%$ of the total phytoplankton carbon biomass (and 7.2 to $67.8 \%$ of the total protist carbon)

Maximum abundances of nanoflagellates were ob-

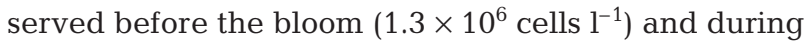
the Phaeocystis globosa bloom after the formation of foam $\left(9.0 \times 10^{6}\right.$ cells $\left.^{-1}\right)$, representing 74.8 and $82.0 \%$, respectively, of the total protists. Nanoflagellate carbon biomass remained very low over the course of the survey, and never accounted for more than $5.6 \%$ of the total protist carbon biomass (Table 2).
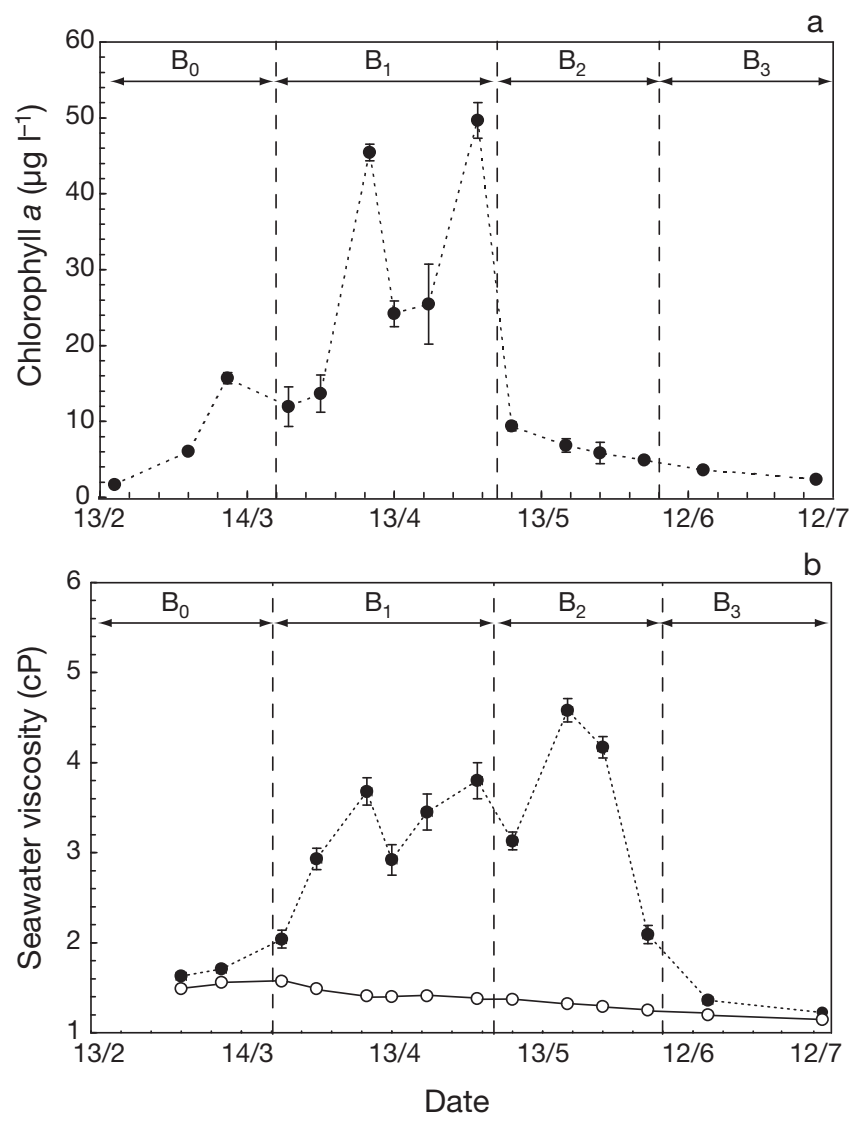

Fig. 1. Time course of (a) chl a concentration ( $\mu \mathrm{g} \mathrm{l}^{-1}$ ) and (b) seawater viscosity $(\mathrm{CP}) . \mathrm{B}_{0}$ is the pre-bloom period, $\mathrm{B}_{1}$ and $\mathrm{B}_{2}$ are the Phaeocystis globosa bloom periods respectively before and after the formation of foam, and $B_{3}$ is the postbloom period. In (B) note the difference between the $(\bullet)$ measured seawater viscosity $\eta_{m}$ and the $(0)$ physically controlled viscosity component $\eta_{T, S}$ estimated from viscosity measurements conducted on filtered $(0.20 \mu \mathrm{m}$ mesh size) seawater from the same samples. Error bars represent \pm SD

Diatoms varied from 6.4 to $71.9 \%$ of total phytoplankton abundance throughout the survey, and the related carbon biomass ranged from 21.4 to $99.8 \%$ of phytoplankton carbon biomass (i.e. 18.3 to $94.6 \%$ of total protist carbon, Table 2). Three distinct species assemblages were identified as previously observed in the southern North Sea (Rousseau et al. 2002): (1) a pre-bloom assemblage (February) dominated by Thalassiosira rotula $\left(20 \mu \mathrm{m}\right.$ length, $0.1 \times 10^{5}$ to $2.2 \times 10^{5}$ cells $\left.\mathrm{l}^{-1}\right)$, Skeletonema costatum $\left(7.5 \mu \mathrm{m}\right.$ length, $0.7 \times 10^{5}$ to $1.5 \times$ $10^{5}$ cells $^{-1}$ ) and Asterionellopsis glacialis (60 $\mu \mathrm{m}$ length,

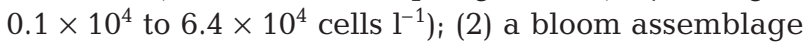
dominated by Chaetoceros sp. (12 $\mu$ m length, $1.8 \times 10^{5}$ to $11.2 \times 10^{5}$ cells $\left.^{-1}\right)$, Rhizosolenia imbricata $(300 \mu \mathrm{m}$ in length, $0.2 \times 10^{5}$ to $2.6 \times 10^{5}$ cells $\mathrm{l}^{-1}$ ), Guinardia delicatula (30 $\mathrm{\mu m}$ length, $0.4 \times 10^{4}$ to $11.4 \times 10^{4}$ cells $\left.\mathrm{l}^{-1}\right)$ and the pennate Pseudonitzschia pseudodelicatissima (35 $\mu \mathrm{m}$ 
Table 2. Abundance (cells $\mathrm{l}^{-1}$ ), relative abundance ( $\%$ of total protists), biomass $\left(\mu \mathrm{gC}^{-1}\right)$ and relative biomass (\% of total protist biomass) of the main protist groups (autotroph and hetero/mixotroph) or species identified over the course of our survey. $\mathrm{B}_{0}$ is the pre-bloom period, $\mathrm{B}_{1}$ and $\mathrm{B}_{2}$ are the Phaeocystis globosa bloom periods respectively before and after the formation of foam, and $\mathrm{B}_{3}$ is the post-bloom period

\begin{tabular}{|c|c|c|c|}
\hline $\begin{array}{l}\text { Trophic status, } \\
\text { group/species, } \\
\text { and bloom period }\end{array}$ & $\begin{array}{c}\text { Relative } \\
\text { abundance } \\
(\%)\end{array}$ & $\begin{array}{l}\text { Biomass } \\
\left(\mu g \mathrm{C}^{-1}\right)\end{array}$ & $\begin{array}{c}\text { Relative } \\
\text { biomass } \\
(\%)\end{array}$ \\
\hline \multicolumn{4}{|l|}{ Autotrophs } \\
\hline \multicolumn{4}{|l|}{ P. globosa } \\
\hline 0.0 & 0.0 & 0.0 & 0.0 \\
\hline $0.8 \times 10^{-6}-5.5 \times 10^{-6}$ & $40.4-80.5$ & $99.8-676.4$ & $7.2-67.8$ \\
\hline $0.0-3.5 \times 10^{-6}$ & $0.0-45.2$ & $0.0-437.7$ & $0.0-54.8$ \\
\hline 0.0 & 0.0 & 0.0 & 0.0 \\
\hline \multicolumn{4}{|l|}{ Nanoflagellates } \\
\hline $0.6 \times 10^{-6}-1.3 \times 10^{-6}$ & $50.8-74.8$ & $1.2-2.0$ & $0.5-5.7$ \\
\hline $0.1 \times 10^{-6}-1.1 \times 10^{-6}$ & $3.3-30.8$ & $0.1-1.9$ & $0.0-0.4$ \\
\hline $2.0 \times 10^{-6}-9.0 \times 10^{-6}$ & $41.7-82.0$ & $0.3-17.3$ & $0.5-3.4$ \\
\hline $1.0 \times 10^{-6}-1.1 \times 10^{-6}$ & $26.9-43.2$ & $1.9-2.0$ & $0.1-0.4$ \\
\hline \multicolumn{4}{|l|}{ Diatoms } \\
\hline $1.6 \times 10^{-5}-5.2 \times 10^{-5}$ & $11.5-31.1$ & $14.8-408.1$ & $40.8-94.9$ \\
\hline $2.3 \times 10^{-5}-17.4 \times 10^{-5}$ & $9.6-45.9$ & $54.9-1877.3$ & $18.3-90.3$ \\
\hline $7.3 \times 10^{-5}-13.4 \times 10^{-5}$ & $6.4-31.7$ & $315.9-476.3$ & $44.0-69.4$ \\
\hline $11 \times 10^{-5}-27.6 \times 10^{-5}$ & $43.4-71.9$ & $331.3-1518.4$ & $79.9-92.7$ \\
\hline \multicolumn{4}{|l|}{ Cryptophyceans } \\
\hline $1.5 \times 10^{-5}-3.5 \times 10^{-5}$ & $10.1-17.6$ & $1.2-2.3$ & $0.1-1.4$ \\
\hline $0.1 \times 10^{-5}-0.7 \times 10^{-5}$ & $0.1-2.6$ & $0.1-1.2$ & $<0.1$ \\
\hline $0.4 \times 10^{-5}-2.7 \times 10^{-5}$ & $0.5-6.4$ & $0.1-0.4$ & $<0.1$ \\
\hline $0.5 \times 10^{-5}-2.7 \times 10^{-5}$ & $0.1-10.7$ & $0.1-0.4$ & $<0.1$ \\
\hline \multicolumn{4}{|l|}{ Hetero/mixotrophs } \\
\hline \multicolumn{4}{|l|}{ Dinoflagellates } \\
\hline $0.1 \times 10^{-4}-4.7 \times 10^{-4}$ & $0.1-3.2$ & $6.6-11.0$ & $0.5-30.7$ \\
\hline $0.8 \times 10^{-4}-3.0 \times 10^{-4}$ & $0.2-1.5$ & $9.3-31.1$ & $0.5-10.4$ \\
\hline $0.5 \times 10^{-4}-60.0 \times 10^{-4}$ & $0.1-14.2$ & $1.1-195.4$ & $0.1-28.5$ \\
\hline $3.6 \times 10^{-4}-6.6 \times 10^{-4}$ & $0.9-2.6$ & $78.9-111.6$ & $6.8-19.0$ \\
\hline \multicolumn{4}{|l|}{ Ciliates } \\
\hline $5.0 \times 10^{-3}-7.0 \times 10^{-3}$ & $0.3-0.5$ & $6.6-12.3$ & $2.8-22.1$ \\
\hline $1.4 \times 10^{-3}-10.0 \times 10^{-3}$ & $0.1-0.4$ & $3.7-24.7$ & $0.1-4.3$ \\
\hline $1.4 \times 10^{-3}-2.8 \times 10^{-3}$ & $0.0-0.1$ & $1.3-10.3$ & $0.2-1.5$ \\
\hline $1.0 \times 10^{-3}-2.6 \times 10^{-3}$ & $0.0-0.1$ & $2.5-5.6$ & $0.3-0.6$ \\
\hline
\end{tabular}

The second peak was strongly dominated by Chaetoceros sp. that reached $2.1 \times 10^{6}$ cells $\mathbf{l}^{-1}$.

Cryptophyceans $(7 \mu \mathrm{m})$ were at times abundant before and after the Phaeocystis globosa bloom, reaching ca. $20 \%$ and $10 \%$, respectively, of total protist abundance (Table 2). The corresponding carbon biomass (0.1 to $0.6 \mu \mathrm{gC} \mathrm{l}^{-1}$ ) was always $<1 \%$ of the total protist carbon biomass.

Dinoflagellates were less abundant with maximum abundance values never exceeding $6.0 \times 10^{5}$ cells $\mathrm{l}^{-1}$, which corresponded to a maximum relative abundance smaller than $15 \%$ (Table 2). Their carbon biomass were nevertheless bounded between 0.3 and $195.4 \mu \mathrm{gC}^{-1}$, and represented $30.0 \%$ and $28.4 \%$ of total protist carbon biomass before the Phaeocystis globosa bloom $\left(\mathrm{B}_{0}\right)$ and after the formation of foam $\left(\mathrm{B}_{2}\right)$, respectively. The dinoflagellate pool was dominated by small forms (25 $\mu \mathrm{m}$ in length) constituting $>70 \%$ of total dinoflagellate abundance followed by large heterotrophic Gyrodinium lachryma (160 $\mu \mathrm{m}$ length, 1 to $11 \%$ ) and Protoperidinium sp. (50 $\mathrm{mm}$ length, 1 to $30 \%$ ).

Finally, ciliated protozoans reached their maximum concentrations before the bloom $\left(7.0 \times 10^{3}\right.$ cells $\left.\mathrm{l}^{-1}\right)$ and during the Phaeocystis globosa bloom before

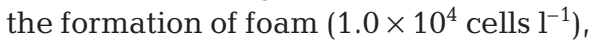
representing $<0.5 \%$ of total protists. These abundances correspond to carbon biomass ranging from 1.5 to 27.6 $\mu \mathrm{gC} \mathrm{l}^{-1}$, representing 0.2 to $23.9 \%$ of length, $0.1 \times 10^{4}$ to $11.2 \times 10^{4}$ cells $1^{-1}$ ); (3) a post-bloom assemblage characterized by Guinardia delicatula $\left(30 \mu \mathrm{m}\right.$ length, $3.8 \times 10^{5}$ to $8.0 \times 10^{5}$ cells $\left.{ }^{-1}\right)$, Leptocylindrus spp. (L. danicus and L. minimus; 20 to $35 \mu \mathrm{m}$ length, $0.7 \times 10^{5}$ to $3.7 \times 10^{5}$ cells $1^{-1}$ ) and the large fine-walled species of the genus Rhizosolenia spp. (R. setigera and $R$. imbricata; $\geq 300 \mu \mathrm{m}$ length, $1.0 \times 10^{4}$ to $7.0 \times$ $10^{4}$ cells $\mathrm{l}^{-1}$ ). Two abundance maxima were observed, the first on April 8 with a concentration of $1.7 \times$ $10^{6}$ cells $\mathrm{l}^{-1}$ when the phytoplankton assemblage was highly dominated by Phaeocystis globosa, and the second on June 15 with a concentration of $2.8 \times 10^{6}{\text { cells } l^{-1}}^{-1}$ when $P$. globosa had disappeared. The first peak was mainly due to chain-forming species such as Chaetoceros sp., G. delicatula and P. pseudodelicatissima. In particular, P. pseudodelicatissima and Chaetoceros sp. were observed to be embedded into P. globosa colonies. total protist carbon biomass. Contributions of dinoflagellates and ciliates to total protist carbon were not negligible particularly before (up to $54 \%$, period $\mathrm{B}_{0}$ ) and during the P. globosa bloom after the formation of foam (0.6 to $30.1 \%$, period $\left.\mathrm{B}_{1}\right)$.

\section{Temporal patterns in Phaeocystis globosa spring bloom}

Four distinct periods were identified according to the previously mentioned chlorophyll concentration, seawater excess viscosity and phytoplankton taxonomy and abundance, and defined according to the following criteria:

(1) A pre-bloom period characterized by the absence of Phaeocystis globosa cells, low chlorophyll concen- 
tration, low seawater excess viscosity and dominated by nanoflagellates;

(2) A bloom period characterized by the presence of Phaeocystis globosa cells and colonies, before the formation of foam in the turbulent surf zone, increasing chlorophyll concentration and excess seawater excess viscosity and dominated by P. globosa;

(3) A bloom period characterized by the presence of Phaeocystis globosa cells and senescent colonies, after the formation of foam in the turbulent surf zone, a sharp decrease in chlorophyll concentration, an additional increase in excess viscosity towards a maximum value, the appearance of ciliates and dinoflagellates and dominated by $P$. globosa and nanoflagellates;

(4) A post-bloom period characterized by the disappearance of Phaeocystis globosa cells, low chlorophyll concentration, low seawater excess viscosity, a decrease in ciliates and an increase in dinoflagellates although protist assemblages remained dominated by diatoms and nanoflagellates.

These 4 periods will be respectively be referred to as $\mathrm{B}_{0}, \mathrm{~B}_{1}, \mathrm{~B}_{2}$ and $\mathrm{B}_{3}$ hereafter.

\section{Gut content and swimming behaviour}

Gut content. The gut content (GC) of Temora longicornis adult females ranged from 0.13 to $1.40 \mathrm{ng}$ chlorophyll individual [ind.] ${ }^{-1}$ and was significantly different among the 4 periods identified above (KW and $\mathrm{J}$ tests, $\mathrm{p}<0.01$, Table 3 ). The temporal pattern of GC (Fig. 2) can be directly related to those observed for chlorophyll concentration, seawater viscosity (Fig. 1) and protist taxonomy (Table 2). Gut content significantly increased (Kendall's $\tau, \mathrm{p}<0.01$ ) from $0.45 \pm 0.02$ to $0.55 \pm 0.08 \mathrm{ng}$ chlorophyll ind. ${ }^{-1}(\bar{X} \pm \mathrm{SD})$ during the pre-bloom period $\mathrm{B}_{0}$, i.e. when diatoms (Thalassiosira rotula, Skeletonema costatum and Asterionellopsis glacialis) constituted the bulk of carbon biomass. Despite the sharp increase in chlorophyll due to Phaeocystis globosa bloom between March 29 and April 30 (period $\mathrm{B}_{1}$; Fig. 1a), GC significantly decreased $(p<0.01)$ from $0.65 \pm 0.04$ ng chlorophyll ind. ${ }^{-1}$

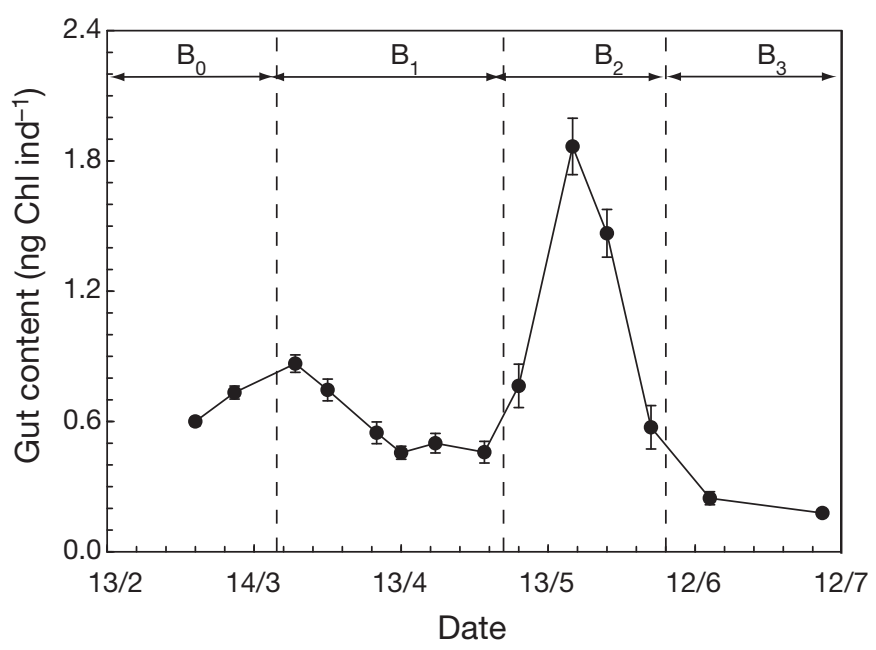

Fig. 2. Temora longicornis. Time course of gut contents GC (ng chlorophyll ind. ${ }^{-1}$ ) of adult females. $\mathrm{B}_{0}$ is the pre-bloom period, $\mathrm{B}_{1}$ and $\mathrm{B}_{2}$ are the Phaeocystis globosa bloom periods respectively before and after the formation of foam, and $B_{3}$ is the post-bloom period. Error bars represent $\pm \mathrm{SD}$

$(\bar{X} \pm \mathrm{SD})$ to $0.34 \pm 0.05 \mathrm{ng}$ chlorophyll ind.$^{-1}$ (Fig. 2) with increasing seawater viscosity (Fig. 1b). Thereafter, GC sharply increased with the formation of foam (period $\mathrm{B}_{2}$ ) to reach a maximum of $1.44 \pm 0.13 \mathrm{ng}$ chlorophyll ind. ${ }^{-1}$ on May 18, despite a 5-fold decrease in chlorophyll concentration and the appearance of heterotrophic protists. Gut content then decreased to $0.43 \pm$ $0.10 \mathrm{ng}$ chlorophyll ind. ${ }^{-1}$ on June 6 (Fig. 2) and finally dropped down to $0.13 \pm 0.01 \mathrm{ng}$ chlorophyll ind. ${ }^{-1}$ after the bloom when $P$. globosa is replaced by large fine walled diatoms (Fig. 2, Tables $2 \& 3$ ).

Swimming paths. Two types of convoluted swimming paths were visually identified for Temora longicornis adult females (Fig. 3). During the pre- and post-bloom periods, swimming paths were relatively isotropic and characterized by their large spatial extent, with distances of mostly 4 to $6 \mathrm{~cm}$ travelled in 20 to $30 \mathrm{~s}$ (Fig. 3a,d). In contrast, during the 2 bloom periods, swimming paths were more localized, with maximal horizontal and vertical extents always less than than $2 \mathrm{~cm}$ and characterized by an alternation

Table 3. Temora longicornis. Ranges of chl a concentration $\left(\mu \mathrm{g}^{-1}\right)$, seawater viscosity $\left(\eta_{m}, \mathrm{cP}\right)$ and the behavioural parameters estimated for adult females; gut content $\left(\mathrm{GC}\right.$, ng chlorophyll ind. $\left.{ }^{-1}\right)$, swimming speed $\left(V, \mathrm{~mm} \mathrm{~s}^{-1}\right)$, net-gross displacement rate (NGDR), swimming activity index $\left(A_{i,} \%\right)$ and fractal dimension $D . \mathrm{B}_{0}$ is the pre-bloom period, $\mathrm{B}_{1}$ and $\mathrm{B}_{2}$ are the Phaeocystis globosa bloom periods respectively before and after the formation of foam, and $\mathrm{B}_{3}$ is the post-bloom period

\begin{tabular}{|c|c|c|c|c|c|c|c|}
\hline $\begin{array}{l}\text { Bloom } \\
\text { period }\end{array}$ & Chl $a\left(\mu g l^{-1}\right)$ & $\eta_{\mathrm{m}}(\mathrm{cP})$ & $\begin{array}{c}\mathrm{GC} \\
\text { (ng chl ind }^{-1} \text { ) }\end{array}$ & $V\left(\mathrm{~mm} \mathrm{~s}^{-1}\right)$ & NGDR & $A_{i}$ & $D$ \\
\hline $\mathrm{B}_{0}$ & $0.78-15.70$ & $1.62-1.71$ & $0.45-0.55$ & $1.12-1.20$ & $0.63-0.67$ & $97.4-96.9$ & $1.18-1.20$ \\
\hline $\mathrm{B}_{1}$ & $11.94-49.68$ & $2.04-3.80$ & $0.35-0.67$ & $0.44-1.02$ & $0.63-0.69$ & $22.4-92.7$ & $1.19-1.52$ \\
\hline $\mathrm{B}_{2}$ & $4.89-9.37$ & $2.09-4.59$ & $0.43-1.44$ & $0.38-0.95$ & $0.65-0.68$ & $42.8-79.0$ & $1.53-1.82$ \\
\hline $\mathrm{B}_{3}$ & $2.58-3.62$ & $1.23-1.36$ & $0.13-0.19$ & $1.10-1.20$ & $0.65-0.66$ & $94.0-99.0$ & $1.23-1.24$ \\
\hline
\end{tabular}




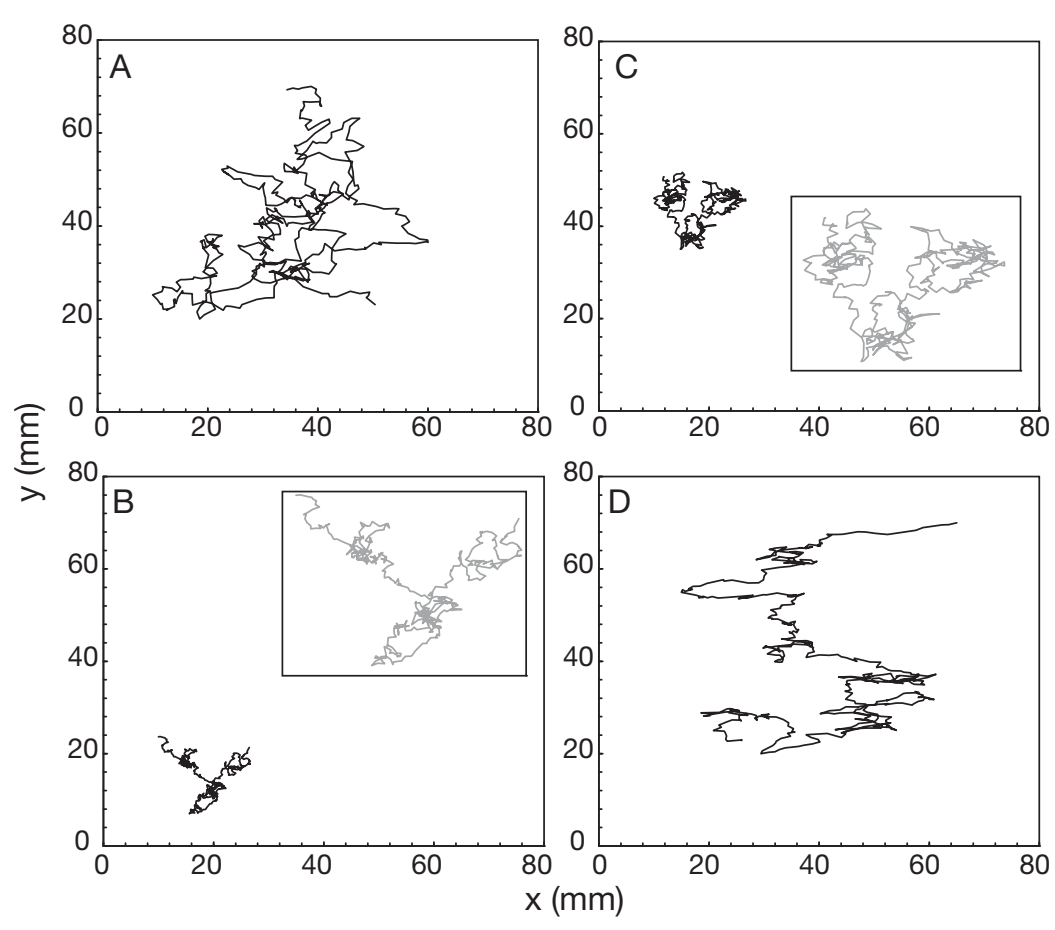

Fig. 3. Temora longicornis. Swimming trajectories of adult females recorded (A) before (period $\mathrm{B}_{0}$ ) and (D) after (period $\mathrm{B}_{3}$ ) the Phaeocystis globosa bloom, and during the bloom $(B)$ before (period $B_{1}$ ) and $(C)$ after (period $B_{2}$ ) the formation of foam. The inserts are magnifications of the actual trajectories between relatively linear and highly convoluted swimming paths (Fig. 3b,c).

Swimming speed, swimming activity index and NGDR. The swimming speed of Temora longicornis adult females ranged from 0.38 to $1.20 \mathrm{~mm} \mathrm{~s}^{-1}(0.76 \pm$ $0.32 \mathrm{~mm} \mathrm{~s}^{-1}, \bar{x} \pm \mathrm{SD}$ ), and significantly differed over the course of the survey (KW test, $\mathrm{p}<0.01$, Fig. 4a, Table 3). The swimming speed recorded during the pre- and post-bloom periods, $\mathrm{B}_{0}(1.16 \pm$ $\left.0.06 \mathrm{~mm} \mathrm{~s}^{-1}\right)$ and $B_{3}\left(1.15 \pm 0.07 \mathrm{~mm} \mathrm{~s}^{-1}\right)$, were not distinguishable $(\mathrm{J}$ test, $\mathrm{p}>0.05$ ) and significantly higher $(\mathrm{p}<0.01)$ than those observed during the bloom periods $\mathrm{B}_{1}\left(0.63 \pm 0.23 \mathrm{~mm} \mathrm{~s}^{-1}\right)$ and $\mathrm{B}_{2}(0.56 \pm$ $0.26 \mathrm{~mm} \mathrm{~s}^{-1}$ ).

The swimming activity index $A_{i}$ (Fig. 4b) is bounded between 22.4 and $99.0(63.1 \pm 30.5, \bar{X} \pm \mathrm{SD})$. Swimming activity $A_{i}$ was maximum during the pre- and post-bloom periods $\mathrm{B}_{0}(97.2 \pm$ $0.4)$ and $B_{3}(96.5 \pm 3.5)$, decreased during the period $B_{1}$ from 92.7 to 22.4 and increased from 42.8 to 79.0 during the period $\mathrm{B}_{2}$ (Fig. 4b). In contrast, the
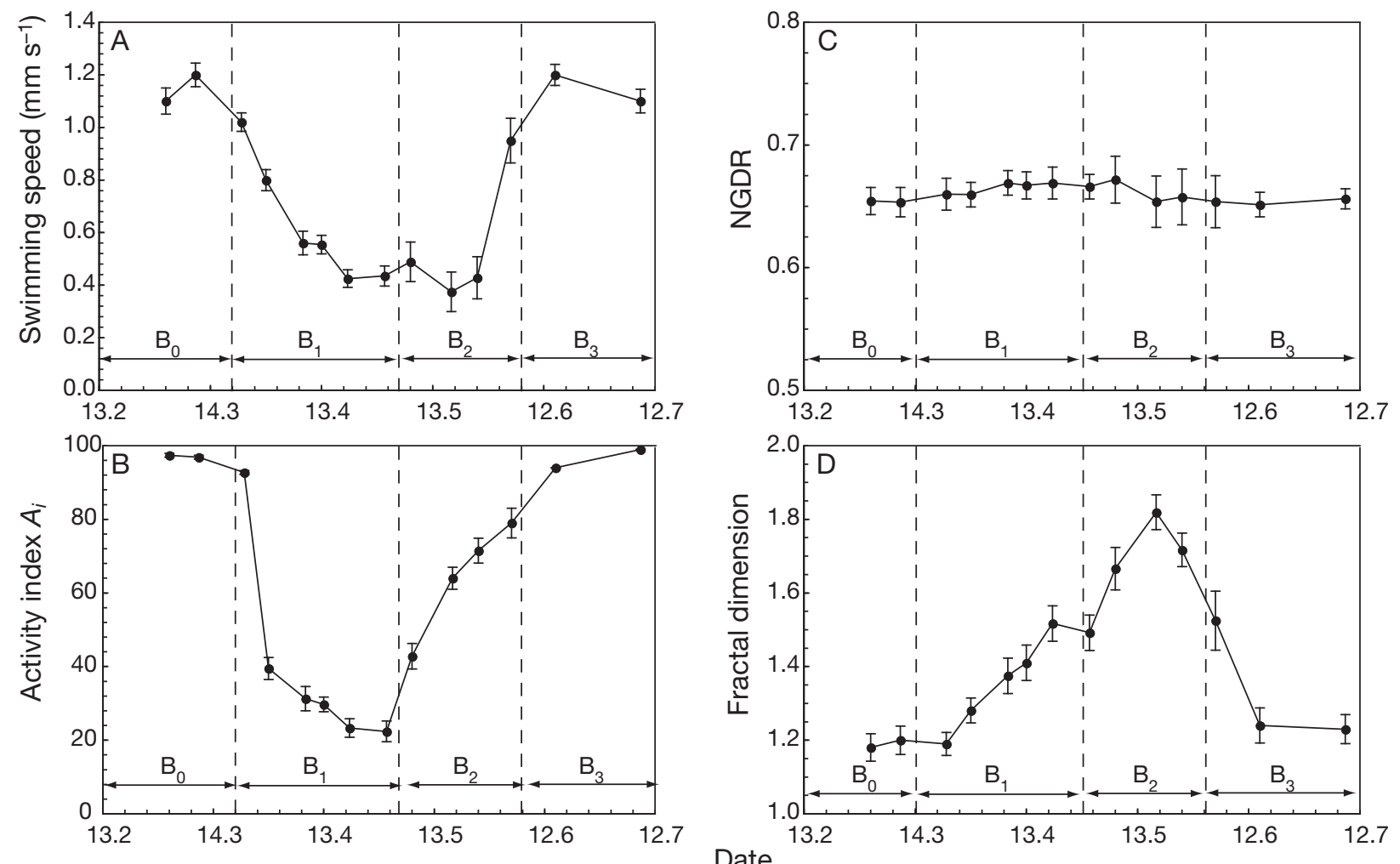

Fig. 4. Temora longicornis. Time course of the behavioural parameters of adult females; (A) swimming speed (mm $\mathrm{s}^{-1}$ ), (B) activity index (\%), (C) NGDR and (D) fractal dimension $D$. $\mathrm{B}_{0}$ is the pre-bloom period, $\mathrm{B}_{1}$ and $\mathrm{B}_{2}$ are the Phaeocystis globosa bloom periods respectively before and after the formation of foam, and $\mathrm{B}_{3}$ is the post-bloom period. Error bars represent $\pm \mathrm{SD}$ 
NGDR of T. longicornis adult females ranged from 0.63 to $0.69(0.66 \pm 0.01, \bar{x} \pm \mathrm{SD})$ and did not exhibit any significant difference over the course of the survey (KW test, p > 0.05, Fig. 4c).

Fractal dimension. Plots of $\log L \delta$ versus $\log \delta$ (Eq. 8) and $N(\lambda)$ versus $\lambda$ (Eq. 10) exhibited very strong linear behaviours over the whole range of available scales (not shown) with coefficients of determination $\left(\mathrm{r}^{2}\right)$ ranging from 0.98 to 0.99 , and always satisfied the 2 optimisation criteria described above. The compass fractal dimension $D_{c}$ and the box-counting fractal dimension $D_{b}$ were not significantly different ( $U$-test, $\mathrm{p}>0.05)$. As a consequence, the results obtained for fractal dimension estimates $D_{c}$ and $D_{b}$ will be referred to as the fractal dimension $D$, where:

$$
D=\frac{1}{N_{c}} \sum_{1}^{N_{c}} D_{C}+\frac{1}{N_{b}} \sum_{1}^{N_{b}} D_{b}
$$

$N_{c}$ and $N_{b}$ are the numbers of compass dimension $D_{c}$ and box-counting dimension $D_{b}$ estimates, respectively $\left(N_{c}=N_{b}=5\right)$.

The fractal dimension $D$ estimated for the swimming paths observed over the course of the survey were significantly different (KW test, $\mathrm{p}<0.01$, Fig. 4d) and exhibited significant differences between each of the 4 periods $\mathrm{B}_{0}, \mathrm{~B}_{1}, \mathrm{~B}_{2}$ and $\mathrm{B}_{3}(\mathrm{~J}$ test, $\mathrm{p}<0.01$, Table 3$)$. The highest and lowest fractal dimensions were found for the pre-bloom period $\mathrm{B}_{0}(D=1.19 \pm 0.01)$ and during the bloom period $\mathrm{B}_{2}$ after the formation of foam $(D=$ $1.68 \pm 0.12$ ). Intermediate values were found for the periods $\mathrm{B}_{3}(D=1.24 \pm 0.01)$ and $\mathrm{B}_{1}(D=1.38 \pm 0.12)$.

Correlation analyses. The potential relationship between chlorophyll concentration, seawater viscosity and the parameters related to the feeding and swimming behaviour of Temora longicornis adult females were investigated through correlation analysis for

Table 4. Temora longicornis. Spearman rank correlations $(\rho)$ between chl a concentration, seawater viscosity $(\eta)$, and the related behavioural parameters estimated for adult females: gut content (GC), swimming speed $(v)$, net-gross displacement rate (NGDR), swimming activity index $\left(A_{i}\right)$, fractal dimension $(D)$ and the size of adult females. $\mathrm{B}_{0}$ is the pre-bloom period, $\mathrm{B}_{1}$ and $\mathrm{B}_{2}$ are the Phaeocystis globosa bloom periods respectively before and after the formation of foam, and $\mathrm{B}_{3}$ is the post-bloom period. ${ }^{*} 5 \%$ significance level, ${ }^{* *} 1 \%$ significance level

\begin{tabular}{|ccccccccr|}
\hline & Chl $a$ & $\eta$ & GC & $v$ & NGDR & $A_{i}$ & $D$ & Size \\
\hline $\mathrm{Chl} a$ & & & & & & & & \\
$\mathrm{~B}_{0}$ & - & 0.15 & 0.50 & 0.44 & 0.01 & -0.22 & 0.32 & 0.20 \\
$\mathrm{~B}_{1}$ & - & $0.83^{* *}$ & $-0.57^{* *}$ & $-0.52^{* *}$ & 0.36 & $-0.58^{* *}$ & $0.46^{* *}$ & -0.37 \\
$\mathrm{~B}_{2}$ & - & $-0.45^{*}$ & -0.05 & $-0.42^{*}$ & 0.39 & $-0.46^{*}$ & 0.32 & 0.24 \\
$\mathrm{~B}_{3}$ & - & 0.55 & 0.44 & 0.32 & 0.19 & -0.53 & 0.41 & -0.23 \\
$\eta$ & & & & & & & & \\
$\mathrm{B}_{0}$ & 0.15 & - & 0.48 & $-0.52^{*}$ & 0.33 & $-0.53^{*}$ & 0.02 & 0.22 \\
$\mathrm{~B}_{1}$ & $0.83^{* *}$ & - & $-0.56^{* *}$ & $-0.75^{* *}$ & 0.26 & $-0.63^{* *}$ & $0.65^{* *}$ & 0.13 \\
$\mathrm{~B}_{2}$ & $-0.45^{*}$ & - & $0.97^{* *}$ & $-0.88^{* *}$ & -0.22 & $0.46^{*}$ & $0.95^{* *}$ & 0.32 \\
$\mathrm{~B}_{3}$ & 0.55 & - & 0.58 & 0.6 & 0.62 & -0.62 & 0.22 & 0.22 \\
\hline
\end{tabular}

each of the 4 periods $\mathrm{B}_{0}, \mathrm{~B}_{1}, \mathrm{~B}_{2}$ and $\mathrm{B}_{3}$ described previously (Table 4). Chlorophyll concentration and seawater viscosity were significantly correlated both positively and negatively during the bloom period respectively before and after the formation of foam. No significant correlations were found between chlorophyll concentration and T. longicornis feeding and swimming behaviour during the pre- and post-bloom periods $\mathrm{B}_{0}$ and $\mathrm{B}_{3}$. In contrast, before the formation of foam, chlorophyll concentration was negatively correlated ( $p<0.01$ ) with gut content, swimming speed and swimming activity and positively correlated with fractal dimension. After the formation of foam, chlorophyll concentration was negatively correlated $(p<0.01)$ with swimming speed and swimming activity (Table 4). During the pre-bloom period $\mathrm{B}_{0}$, swimming speed and swimming activity were negatively correlated $(\mathrm{p}<$ $0.05)$ with seawater viscosity. During the bloom, gut content and swimming activity were negatively and positively correlated $(p<0.01$ ) with viscosity before and after the formation of foam, respectively. In contrast, swimming speed and fractal dimension respectively were always negatively and positively correlated ( $p<0.01$ ) to viscosity. No significant correlations were found between the feeding and swimming behaviour of $T$. longicornis and seawater viscosity during the post-bloom period $\mathrm{B}_{3}$.

\section{DISCUSSION}

\section{Chlorophyll concentration, seawater viscosity and foam formation}

The shift from positive to negative significant correlations between chlorophyll concentration and seawater viscosity before and after the foam formation (Table 4) is congruent with a recent mechanistic explanation (Seuront et al. 2006) suggesting that the disruption of the mucilaginous colonial matrix by turbulent mixing leads to (1) the formation of foam and the release of flagellated cells, (2) a decrease in chl a concentration (Fig. 1a) as a significant proportion of cells are entrained within the foam during the emulsion process, and finally (3) the decoupling between the viscous (i.e. colonial polymeric materials) and nonviscous (flagellated cells) contribution of Phaeocystis globosa to bulk phase seawater properties. This is also consistent with the dynamics of transparent exopolymeric particles (TEP) produced 
by P. globosa (Mari et al. 2005). During the growth phase of P. globosa, TEP and chl a concentration were positively correlated. In contrast, the release of large TEP from the mucilaginous matrix of $P$. globosa colonies after colony disruption leads to a negative correlation between TEP and chl a concentration. The variety of dissolved particulate carbohydrates produced during a $P$. globosa bloom (see van Rijssel et al. 2000 for a review) are known to coagulate spontaneously via colloidal precursors and to form gel-like material in the shape of spheres, strings or sheets (Passow 2000). They are then likely to contribute to the formation of microscopic polymer gels in seawater (Chin et al. 1998) and, in turn, to affect seawater viscosity and the related microscale processes such as nutrient uptake, viral infection, feeding and swimming behaviour.

\section{Chlorophyll concentration, seawater viscosity and zooplankton gut content}

On the size mismatch and mechanical hindrance hypothesis. While the research devoted to relate seawater viscosity measurement to the quality and the quantity of dissolved and particulate carbohydrates and transparent exopolymeric particles is still to be done, the exudates and transparent exopolymeric particles derived from a Phaeocystis globosa dominated community have been shown to inhibit copepod feeding on co-occurring phytoplankton preys (Dutz et al. 2005). This is consistent with the negative correlations observed between the gut content of Temora longicornis adult females (Fig. 2) and both chlorophyll concentration and seawater viscosity during the first phase of the bloom (period $\mathrm{B}_{1}$; Fig. 1, Table 4). Despite a 4 -fold increase in chlorophyll concentration (Fig. 1a), gut contents significantly decreased (Fig. 2). This is congruent with the decrease in diatom ingestion (up to $25 \%$ ) observed during blooms of P. globosa (Gasparini et al. 2000, Koski et al. 2005), and suggests a defence strategy against zooplankton grazers through (1) the mechanical hindrance related to the increase in seawater viscosity and/or (2) the size mismatch related to the embedding of $P$. globosa cells and non-motile preys (mainly diatoms) in the colonial matrix (Koski et al. 2005). As a consequence, while P. globosa, Chaetoceros sp., Rhizosolenia imbricata, Guinardia delicatula, and Pseudonitzschia pseudodelicatissima accounted for more than $80 \%$ of the total protist abundance during the period $\mathrm{B}_{1}$, the increase in chlorophyll concentration did not imply any increase in food availability (Fig. 5b).

In contrast, after the formation of foam (period $\mathrm{B}_{2}$ ), Temora longicornis gut contents increased (Fig. 2) des- pite a decrease in chlorophyll concentration (Fig. 1a) and a further increase in seawater viscosity (Fig. 1b). The foam formation, and the related colony disruption, leads to the release of flagellated colony cells in the bulk phase seawater (e.g. Peperzak et al. 2000), together with the diatoms still embedded in the disrupted colonial matrix (Seuront et al. 2006). This potentially results in an increase in food availability (Fig. 5c) despite the overall decrease in chlorophyll concentration (see Fig. 1a). This is also consistent with the reported zooplankton grazing on Phaeocystis sp. solitary cells at high concentration (Cotonnec et al. 2001) and demonstrates that even elevated viscosity (i.e. up to $4.6 \mathrm{cP}$; Fig. 1b) does not inhibit zooplankton grazing on phytoplankton cells due to mechanical hindrance as previously suggested (Weisse et al. 1994).

From size mismatch and mechanical hindrance to prey switching behaviour. The high and relatively stable egg production and hatching success observed throughout the survey (Flamme 2004) show that Temora longicornis were able to sustain their production rates despite a drastic change in the taxonomy of the protist resource. Given the negative correlation between gut content and chlorophyll concentration, this suggests that the gut contents observed during the periods $\mathrm{B}_{1}$ and $\mathrm{B}_{2}$ (Fig. 2, Table 3 ) may be triggered by the temporal dynamic of the protist community and the related prey switching behaviour.

Three non-conflicting hypotheses can then be suggested to explain the decrease in gut content observed during the period $\mathrm{B}_{1}$ :

(1) A sharp decrease occurs in cryptophyceans (from $14.7 \pm 3.2$ to $1.5 \pm 0.9 \%$ of total protists) that are actively selected by Temora longicornis in the eastern English Channel (Cotonnec et al. 2001) during period $\mathrm{B}_{1}$, together with the dominance of toxin producers (Pseudonitzschia pseudodelicatissima; e.g. Adams et al. 2006). Although this potential prey avoidance still needs to be confirmed, it is consistent with the prey switching behaviour from phytoplankton to microzooplankton previously suggested for $T$. longicornis during Phaeocystis globosa blooms (e.g. Gasparini et al. 2000; Fig. 5b).

(2) Heterotrophic ciliates are reported to be actively grazed by copepods; see Sanders \& Wickham (1993) for a review. Their ingestion by copepods may then weaken the gut content signal (chl a) when compared with a true phytoplankton-based diet. The high nutritive value of ciliates (Gifford 1991) allows for a better growth and survival of copepods (Sanders \& Wickham 1993), and is consistent with the lack of decrease in production rate and hatching success despite the decrease in gut content.

(3) Ciliates also exert high grazing pressure on phytoplankton $\left(>100 \% \mathrm{~d}^{-1}\right.$; Sautour et al. 2000), and 


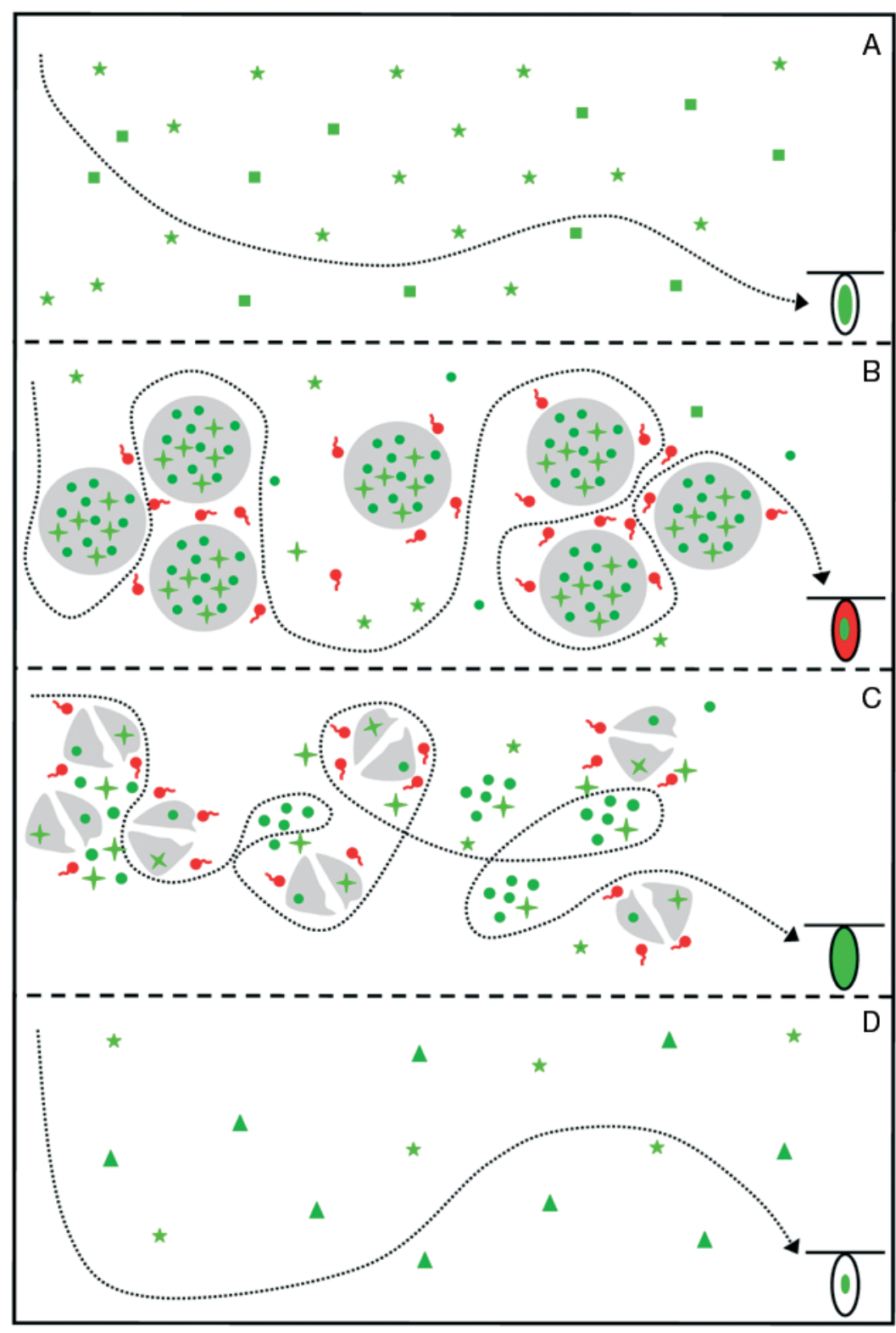

Fig. 5. Temora longicornis. Schematic illustration of feeding and swimming behaviour of adult females over the course of a Phaeocystis globosa spring bloom. (A) Before and (D) after the P. globosa bloom, gut contents are directly controlled by chl a concentrations and T. longicornis do not exhibit any specific foraging behaviour. In contrast ( $\mathrm{B} \& \mathrm{C}$ ), during the bloom $T$. longicornis exhibit elevated foraging activity despite low and high gut contents (B) before and (C) after the formation of foam, respectively. Before the formation of foam (B), phytoplankton cells are unavailable (or decreased drastically, e.g. cryptophyceans) or unsuitable to T. longicornis as they are embedded in the mucilaginous colonial materials (e.g. diatoms) or potentially toxic species (e.g. Pseudonitzschia pseudodelicatissima). After the formation of foam (C), despite a lower chl a concentration, P. globosa cells released from mucilaginous materials along with colonial fragments containing embedded phytoplankton cells become available to grazers. As egg production did not exhibit any significant differences over the duration of the survey, it is also suggested that T. longicornis have the ability to switch their feeding behaviour from phytoplankton to microzooplankton (A-B) and from microzooplankton to phytoplankton (B-C), depending on the availability of $P$. globosa cells. $(\bullet)$ P. globosa cells, $(\star,+, \square, \mathbf{1})$ phytoplankton cells other than P. globosa and ( $\checkmark)$ microzooplankton protists hence, may compete for food resource with copepods. This trophic competition is consistent with the observed decrease in copepod gut contents coinciding with the peak of ciliate abundance (Acineta sp. and tintinnids).

In contrast, the high gut contents observed during period $\mathrm{B}_{2}$ (Fig. 5c) may originate from active feeding on sheets of the disrupted colonial matrix and embedded phytoplankton cells (Koski et al. 2005), the sharp increase in abundance and biomass of dinoflagellates (Table 2) that typically represent a significant fraction of Temora longicornis diet (20 to $40 \%$; Koski et al. 2005), and the shift from potentially toxic small sized diatoms (e.g. Pseudonitzschia pseudodelicatissima) to more palatable large cells (e.g. Guinardia striata, Leptocylindrus danicus).

Finally, at the end of the survey (period $\mathrm{B}_{3 i}$ Fig. 5d) low gut content values may originate from both the decrease in heterotrophic protist abundance and the disappearance of Phaeocystis globosa senescent colonies, thus confirming the hypothesis of significant grazing on both these prey types after foam formation (period $\mathrm{B}_{2}$ ).

\section{Chlorophyll concentration, seawater viscosity and swimming behaviour}

The behavioural properties of Temora longicornis adult females suggest a shift in their foraging activity related to the temporal dynamics of the Phaeocystis globosa bloom. While the significant decrease observed in their swimming speed during the bloom (i.e. periods $\mathrm{B}_{1}$ and $\mathrm{B}_{2}$; Fig. $4 \mathrm{a} \&$ Table 3 ) might be an adaptive strategy to an increase in viscosity, this is very unlikely as the energy cost of swimming for $T$. longicornis represents only a negligible fraction of the total energy consumption (see Table 5 in van Duren et al. 2006). Changes in copepod swimming behaviour could, however, also be a response to the spatial distribution of prey organisms. According to the optimal foraging theory (Pyke 1984), organisms living in highly heterogeneous environments 
could develop strategies to exploit high density patches and then optimise the energy required to capture a given amount of food. This can be achieved by increasing the complexity of swimming paths with increasing food density and/or decreasing the swimming speed or the motility in food patches, thus resulting in an area-restricted searching strategy (e.g. Jonsson \& Johansson 1997). The time course of fractal dimension $D$ (Fig. 4 d) indicates an increased foraging activity during the P. globosa bloom (i.e. periods $\mathrm{B}_{1}$ and $B_{2}$ ) that might be related to more patchy food distributions. This is consistent with recent observations showing an increase in chl a patchiness during the P. globosa bloom in the coastal waters of the eastern English Channel for scales relevant to copepods, i.e. 5 to $50 \mathrm{~cm}$ (Seuront et al. 2007). Healthy and senescent $P$. globosa colonies and their embedded cells are also likely to contribute to this patchiness. Before and after the $P$. globosa bloom, chl $a$ is more homogeneously distributed (Seuront et al. 2007), resulting in more rectilinear swimming paths (Figs. 3a,b \& 5a,d). The gut contents are then directly controlled by the amount of chl $a$ in the environment. In contrast, during the bloom chl $a$ is more heterogeneously distributed (Fig. 5b,c) and the microscale hotspots of organic matter related to colony formation and/or disruption are also likely to represent a secondary source of patchiness for bacteria and microzooplankton grazers. This results in more convoluted swimming paths related to an area-restricted searching strategy of copepods preying on microzooplankton organisms before the formation of foam (period $\mathrm{B}_{1}$; Fig. 5b). This is supported by the sustainability of $T$. longicornis egg production (Flamme 2004) despite low gut contents (Fig. 2) and is consistent with the previously mentioned relative unavailability and/or unsuitability of the phytoplankton resource, a potential trophic competition with large ciliates and the subsequent decrease in chl a gut content (Fig. 5b). After the foam formation, convoluted swimming paths might also be related to an area-restricted searching strategy of copepods preying on phytoplankton cells released in the bulk phase seawater from the mucilaginous materials after the formation of foam, on senescent colonies and/or on large fine walled diatoms still embedded in colonial materials (Fig. 5c). The steady behaviour of the NGDR over the course of the bloom confirms previous studies stating that it is a far less accurate and ecologically relevant index of curviness than the fractal dimension; see Seuront et al. (2004) for a discussion.

While this issue is beyond the scope of the present work, it is finally suggested that the individual-scale behavioural processes observed in response to fluctuations in the biophysical properties of the local environment ultimately are likely to cascade from the scale of the individual grazers up to larger scale and to influence critical processes such as biogeochemical fluxes through their control of zooplankton trophodynamics and production rates. This is especially relevant in the framework of Phaeocystis sp. blooms, given the nearglobal distribution and the key role played by the genus Phaeocystis in the ocean-atmosphere transfers.

Acknowledgements. We acknowledge the captain and the crew of the NO 'Sepia II' for their help during the sampling experiment, and 2 anonymous reviewers whose comments and criticisms greatly improved a previous version of this work. E. Lecuyer and G. Flamme are acknowledged for their contribution to the field work. This work was supported by the CPER 'Phaeocystis', PNEC 'Chantier Manche OrientaleSud Mer du Nord', Centre National de la Recherche Scientifique, Université des Sciences et Technologies de Lille, Australian Research Council and Flinders University.

\section{LITERATURE CITED}

Adams NG, MacFadyen A, Hickey BM, Trainer VL (2006) The nearshore advection of a toxigenic Pseudo-nitzschia bloom and subsequent domoic acid contamination of intertidal bivalves. Afr J Mar Sci 28:271-276

Bratbak G, Jacobsen A, Heldal M (1998) Viral lysis of Phaeocystis pouchetii and bacterial secondary production. Aquat Microb Ecol 16:11-16

> Chen YQ, Wang N, Zhang P, Zhou H, Qu LH (2002) Molecular evidence identifies bloom-forming Phaeocystis (Prymensiophyta) from coastal waters of southeast China as Phaeocystis globosa. Biochem Syst Ecol 30:15-22

$>$ Chin WC, Orellana MV, Verdugo P (1998) Spontaneous assembly of marine dissolved organic matter into polymer gels. Nature 391:568-572

> Cotonnec G, Brunet C, Sautour B, Thoumelin G (2001) Nutritive value and selection of food particles by copepods during a spring bloom of Phaeocystis sp. in the English Channel, as determined by pigment and fatty acid analyses. J Plankton Res 23:693-703

Dagg MJ, Wyman KD (1983) Natural ingestion rates of the copepods Neocalanus plumchrus and N. cristatus calculated from gut contents. Mar Ecol Prog Ser 13:37-46

$>$ Dam HG, Peterson WT (1993) Seasonal contrasts in the diel vertical distribution, feeding behavior and grazing impact of the copepod Temora longicornis in Long Island Sound. J Mar Res 51:561-594

Dutz J, Klein Breteler WCM, Kramer G (2005) Inhibition of copepod feeding by exudates and transparent exopolymer particles (TEP) derived from a Phaeocystis globosa dominated phytoplankton community. Harmful Algae 4: 929-940

Flamme G (2004) Effets de la nourriture et de la temperature sur les triats du cycle de vie du copépode Temora longicornis (Müller): couplage entre un suivi in situ et expérimental. MSc thesis, Université des Sciences et Technologies de Lille

Fransz HG, Gonzalez SR, Cadée GC, Hansen FC (1992) Longterm change of Temora longicornis (Copepoda, Calanoida) abundance in a Dutch tidal inlet (Marsdiep) in relation to eutrophication. Neth J Sea Res 30:23-32

> Gasparini S, Daro MH, Antajan E, Tackx M, Rousseau V, Parent JY, Lancelot C (2000) Mesozooplankton grazing during the Phaeocystis globosa bloom in the southern bight of the North Sea. J Sea Res 43:345-356 
Gifford DJ (1991) The protozoan-metazoan trophic link in pelagic ecosystems. J Eukaryot Microbiol 38:81-86

Jenkinson IR, Biddanda BA (1995) Bulk-phase viscoelastic properties of seawater: relationship with plankton components. J Plankton Res 17:2251-2274

> Jonsson PR, Johansson M (1997) Swimming behaviour, patch exploitation and dispersal capacity of a marine benthic ciliate in flume flow. J Exp Mar Biol Ecol 215:135-153

Klein Breteler WCM, Koski M (2003) Development and grazing of Temora longicornis (Copepoda, Calanoida) nauplii during nutrient limited Phaeocystis globosa blooms in mesocosms. Hydrobiologia 491:185-192

Koski M, Dutz J, Klein Breteler WCM (2005) Selective grazing of Temora longicornis in different stages of a Phaeocystis globosa bloom-a mesocosm study. Harmful Algae 4: 915-927

Mackas DL, Bohrer R (1976) Fluorescence analysis of zooplankton gut contents and an investigation of diel feeding patterns. J Exp Mar Biol Ecol 25:77-85

Mari X, Rassoulzadegan F, Brussaard CPD, Wassmann P (2005) Dynamics of transparent exopolymeric particles (TEP) production by Phaeocystis globosa under N- or Plimitation: a controlling factor of the retention/export balance. Harmful Algae 4:895-914

Menden-Deuer S, Lessard EJ (2000) Carbon to volume relationships for dinoflagellates, diatoms, and other protist plankton. Limnol Oceanogr 45:569-579

- Menden-Deuer S, Lessard EJ, Satterberg J (2001) Effect of preservation on dinoflagellate and diatom cell volume and consequences for carbon biomass predictions. Mar Ecol Prog Ser 222:41-50

> Nejstgaard JC, Tang KW, Steinke M, Dutz J, Koski M, Antajan E, Long JE (2007) Zooplankton grazing on Phaeocystis: a quantitative review and future challenges. Biogeochemistry 83:147-172

Passow U (2000) Formation of transparent exopolymer particles, TEP, from dissolved precursor material. Mar Ecol Prog Ser 192:1-11

Paulmier G (1997) Atlas des Diatomophycées des côtes françaises et des aires océaniques adjacentes. IFREMER, DRV-RH-RST 97/14

Peperzak L, Colijn F, Vriegling EG, Gieskes WWC, Peeters JCH (2000) Observations of flagellates in colonies of Phaeocystis globosa (Prymnesiophyceae): a hypothesis for their position in the life cycle. J Plankton Res 22:2181-2203

Putt M, Stoecker DK (1989) An experimentally determined carbon:volume ratio for marine 'oligotrichous' ciliates from estuarine and coastal waters. Limnol Oceanogr 34: 1097-1103

Pyke JH (1984) Optimal foraging theory: a critical review. Annu Rev Ecol Syst 15:523-575

Ricard M (1987) Atlas du phytoplancton marin. Diatomophycées. Centre National de la Recherche Scientifique, Paris

Rousseau V, Mathot S, Lancelot C (1990) Calculating carbon biomass of Phaeocystis sp. from microscopic observations. Mar Biol 107:305-314

Rousseau V, Vaulot D, Casotti R, Cariou V, Lenz J, Gunkel J, Baumann M (1994) The life cycle of Phaeocystis (Prymnesiophyceae): evidence and hypotheses. J Mar Syst 5:23-39

Rousseau V, Leynaert A, Daoud N, Lancelot C (2002) Diatom succession, silicification and silicic acid availability in Belgian coastal waters (Southern North Sea). Mar Ecol Prog Ser 236:61-73

Saiz E, Rodriguez V, Alcaraz M (1992) Spatial distribution and

Initial editorial responsibility: Howard Browman, Storebø, Norway; Final editorial responsibility: Matthias Seaman, Oldendorf/Luhe, Germany feeding rates of Centropages typicus in relation to frontal hydrographic structures in the Catalan Sea (Western Mediterranean). Mar Biol 112:49-56

Sanders RW, Wickham SA (1993) Planktonic protozoa and metazoan: predation, food quality and population control. Aquat Microb Ecol 7:197-223

Sautour B, Artigas LF, Delmas D, Herbland A, Laborde P (2000) Grazing impact of micro- and mesozzoplankton during a spring situation in coastal waters off the Gironde estuary. J Plankton Res 22:531-552

Schoemann V, Becquevort S, Stefels J, Rousseau V, Lancelot C (2005) Phaeocystis blooms in the global ocean and their controlling mechanisms: a review. J Sea Res 53:43-66

> Seuront L (2005) Hydrodynamical and tidal controls of smallscale phytoplankton patchiness. Mar Ecol Prog Ser 302: 93-101

Seuront L (2006) Effect of salinity on the swimming behaviour of the estuarine calanoid copepod Eurytemora affinis. J Plankton Res 28:805-813

> Seuront L, Hwang JS, Tseng LC, Schmitt FG, Souissi S, Shih CT, Wong CK (2004) Individual variability in the swimming behavior of the tropical copepod Oncaea venusta (Copepoda: Poecilostomatoida). Mar Ecol Prog Ser 283: 199-217

Seuront L, Vincent D, Mitchell JG (2006) Biologically-induced modification of seawater viscosity in the Eastern English Channel during a Phaeocystis globosa spring bloom. J Mar Syst 61:118-133

Seuront L, Lacheze C, Doubell MJ, Seymour JR and others (2007) The influence of Phaeocystis globosa on microscale spatial patterns of chlorophyll $a$ and bulk-phase seawater viscosity. Biogeochemistry 83:173-188

Siegel S, Castellan NJ (1988) Nonparametric statistics. McGraw-Hill, New York

Sournia A (1986) Atlas du phytoplancton marin. Cyanophycées, Dictyophycées, Dinophycées, Radinophycées. Centre National de la Recherche Scientifique, Paris

Strickland JDH, Parsons TR (1972) A practical handbook of seawater analysis. Bull Fish Res Board Can 167, Ottawa

Tang KW (2003) Grazing and colony size development in Phaeocystis globosa (Prymnesiophyceae): the role of a chemical signal. J Plankton Res 25:831-842

Tomas CR (ed) (1997) Identifying marine phytoplankton. Academic Press, San Diego, CA

Utermöhl H (1958) Zur Vervollkommnung der quantitativen Phytoplankton-Methodik. Mitt Int Ver Theor Angew Limnol 9:1-38

> van Duren L, Stamhuis EJ, Videler JJ (2003) Copepod feeding currents: flow patterns, filtration rates and energetics. J Exp Biol 206:255-267

van Rijssel M, Hamm CE, Gieskes WC (1997) Phaeocystis globosa (Prymnesiophyceae) colonies: hollow structures built with small amounts of polysaccharides. Eur J Phycol 32: 185-192

> van Rijssel M, Janse I, Noordkamp DJB, Gieskes WWC (2000) An inventory of factors that affect polysaccharide production by Phaeocystis globosa. J Sea Res 43:297-306

Verity PG, Whipple SJ, Nejstgaard JC, Alderkamp AC (2007) Colony size, cell number, carbon and nitrogen contents of Phaeocystis pouchetii from western Norway. J Plankton Res 29:359-367

Weisse T, Tande K, Verity P, Hansen F, Gieskes W (1994) The trophic significance of Phaeocystis blooms. J Mar Syst 5: $69-79$

Submitted: November 14, 2006; Accepted: November 12, 2007 Proofs received from author(s): June 20, 2008 